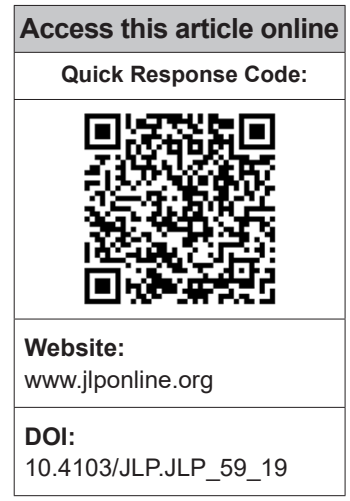

Department of Microbiology, Sri Ramachandra Institute for Higher Education and Research, Chennai,

Tamil Nadu, India

Address for correspondence:

Dr. K. V. L. Aishwarya,

Department of

Microbiology, Sri Ramachandra Institute

for Higher Education and Research,

Chennai - 600 116,

Tamil Nadu, India.

E-mail: mailaishmicro@ gmail.com

Submission: 08-04-2019 Accepted: 07-11-2019

\title{
Co occurrence of two 16S rRNA methyltrasferases along with NDM and OXA 48 like carbapenamases on a single plasmid in Klebsiella pneumoniae
}

\author{
K. V. L. Aishwarya, P. V. Geetha, M. Shanthi, S. Uma
}

\begin{abstract}
:
BACKGROUND: The carbapenemase-encoding genes, $b a_{N D M-}$ and bla ${ }_{O X A-48-l i k e}$, confer resistance to all the known beta-lactams and are encountered along with other beta-lactamase-encoding genes and/or 16S ribosomal RNA (rRNA)-methylating genes. The co-occurrence of $b / a_{N D M}$ and bla $a_{O X A-48-l i k e}$ on a single plasmid is a rare occurrence.
\end{abstract}

AIM AND OBJECTIVE: The purpose of the study was to characterize the plasmids in Klebsiella

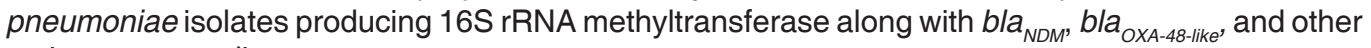
resistance encoding genes.

MATERIALS AND METHODS: One-hundred and seventeen $K$. pneumoniae clinical isolates which were resistant to aminoglycosides were collected. Polymerase chain reaction-based screening for

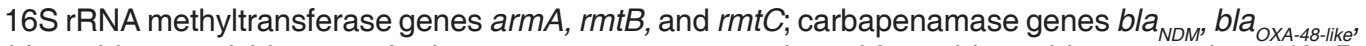

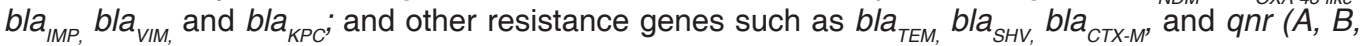
and $\mathcal{S}$ ) determinants $a c c\left(6^{\prime}\right) \mathrm{l} b$-cr was performed. Conjugation experiment was carried out for seven isolates that anchored $b / a_{N D M}$ and $b l a_{O X A-48-\text { like }}$ along with any one of the $16 \mathrm{~S} \mathrm{rRNA}$ methyltransferases. The plasmid-based replicon typing for different plasmid-incompatible $(\mathrm{Inc})$ group was performed on the conjugatively transferable plasmids.

RESULTS: Among the 16S rRNA methyltransferases, armA was more predominant. bla $a_{N D M}$ and bla $_{\text {OXA-48-ike }}$ were present in $56(47.86 \%)$ and $22(18.80 \%)$ isolates, respectively. Out of seven isolates which were conjugatively transferable, only four had $b / a_{N D M}$ and $b l a_{O X A-48-\text { like }}$ on the same plasmid and they belonged to Inc $\mathrm{N}$ and $\mathrm{A} / \mathrm{C}$ replicon. Three isolates co-harbored $16 \mathrm{~S}$ rRNA methyltransferases armA, rmtB, and $r m t C$, and out of the them, one isolate harbored two 16S rRNA methyltransferases $\operatorname{arm} A$ and $r m t B$, on the single-plasmid replicon $\mathrm{A} / \mathrm{C}$.

CONCLUSION: This is the first report revealing the coexistence of $b a_{N D M}$ and $b l a_{O X A-48 / \text { like }}$ co-harboring two $16 \mathrm{~S}$ rRNA methylases on a single conjugative plasmid replicon belonging to incompatibility group A/C.

Key words:

$16 \mathrm{~S}$ ribosomal RNA methyltransferase, A/C replicon, $b / a_{N D M}, b / a_{\text {OXA-48 like, }}$, co-harboring, Klebsiella pneumoniae

\section{Introduction}

A minoglycosides are highly potent Abroad-spectrum antibiotics

This is an open access journal, and articles are distributed under the terms of the Creative Commons Attribution-NonCommercial-ShareAlike 4.0 License, which allows others to remix, tweak, and build upon the work non-commercially, as long as appropriate credit is given and the new creations are licensed under the identical terms.

For reprints contact: reprints@medknow.com with desirable properties for treating life-threatening infections. The resistance mechanisms exhibited by bacteria against aminoglycoside are as follows: (1) acquired lipid modification that makes the cell wall

How to cite this article: L. Aishwarya KV, Geetha PV, Shanthi M, Uma S. Co occurrence of two 16S rRNA methyltrasferases along with NDM and OXA 48 like carbapenamases on a single plasmid in Klebsiella pneumoniae. J Lab Physicians 2019;11:305-11. 
impermeable; (2) aminoglycoside-modifying enzymes that modify the antibiotic at specific sites, making it inactive; and (3) active expulsion of the drug by efflux mechanism.

A novel mechanism of resistance to aminoglycoside was first discovered in 2003 in Pseudomonas and Enterobacteriaceae, ${ }^{[1,2]}$ in which the aminoglycoside-binding site is modified enzymatically by $16 \mathrm{~S}$ ribosomal RNA (rRNA) methyltransferase, commonly known as RMTases. The $16 \mathrm{~S}$ methyltransferases which are intrinsically found in both Streptomyces spp. and Micromonospora spp. have now been identified in other bacteria as a result of the uptake of a plasmid containing the RMTase encoding gene. ${ }^{[3]}$ Till date, 11 RMTases have been identified, of which $\operatorname{arm} A, r m t B$, and $r m t C$ are more frequent among Enterobacteriaceae. ${ }^{[4,5]}$

Aminoglycosides are often used as adjunct drugs for treatment, in combination with other classes of antibiotics. The $16 \mathrm{~S}$ methylases are frequently associated with extended-spectrum beta-lactamases (ESBL), carbapenemases, and plasmid-mediated quinolone-resistant (PMQR) genes. ${ }^{[3,5]}$ In Enterobacteriaceae, 16S rRNA methyltransferases have been found to occur with $b l a_{N D M}{ }^{[6]}$ and rarely with $b l a_{O X A-48-l i k e}{ }^{[7,8]}$

Enterobacteriaceae harboring all the above but with single $16 \mathrm{~S}$ rRNA methyltransferases have been reported from India, Singapore, Turkey, Oman, Switzerland, and France. ${ }^{[9-11]}$ However, the co-occurrence of two $16 \mathrm{~S}$ rRNA methyltransferases along with $b l a_{N D M^{\prime}} b l a_{\text {OXA-48-like, }}$ and other resistant determinants on a single-plasmid replicon has not been reported till date. The presence of these genes on plasmid enables their spread to other bacterial species by horizontal gene transfer. The emergence of such multidrug-resistant bacteria is a cause for concern globally.

Classification of plasmids into incompatible (Inc) groups is necessary because specific Inc groups have been associated with virulence and are of epidemiological importance. ${ }^{[5]}$ The plasmid Inc grouping is based on the fact that two plasmids belonging to the same Inc group cannot proliferate in the same cell line. With this as basis, Carattoli et al. in 2005 designed a polymerase chain reaction (PCR)-based replicon typing, in which 18 sets of primers were used to recognize the coding sequence of rep $A$ genes, the cis-repeats of the origin of replication, and the counter transcript RNA interference. ${ }^{[12]}$

In this context, the aim of this study was to detect the co-occurrence of the most common $16 \mathrm{~S}$ methylases arm $A$, $r m t B$, and $r m t C$ with ESBL-encoding genes $\left(b l a_{T E M^{\prime}} b l a_{S H V}\right.$, and $\left.b l a_{C T X-M}\right)$, carbapenemase-encoding genes $\left(b l a_{I M P}\right.$, $b l a_{V I M^{\prime}} b l a_{K^{\prime} C^{\prime}} b l a_{N D M^{\prime}}$ and $\left.b l a_{\text {OXA-like }}\right)$, and PMQR-encoding genes ( $q n r$ determinants and $\left.a a c\left(6^{\prime}\right)-I b-c r\right)$.

\section{Materials and Methods}

\section{Ethical approval}

The study was approved by the institutional ethical committee (IEC-NI/15/APR/6/18).

\section{Bacterial isolates}

The study included 117, nonrepetitive, amikacin-resistant clinical isolates of Klebsiella pneumoniae, collected over a period of 6 months (June 2015-December 2015). The isolates were obtained from specimens such as urine (65), exudates (27), blood (14), and respiratory secretions (11). All the isolates were speciated based on conventional methods or VITEK-2 system (Vitek-2 GN-card; BioMerieux, Brussels, Belgium).

Antibiotic susceptibility testing and minimum inhibitory concentration

The disc diffusion technique and determination of minimum inhibitory concentration (MIC) were performed in accordance with the Clinical Laboratory Standard Institute, 2016. ${ }^{[13]}$ The antibiotics tested were amikacin $(30 \mu \mathrm{g})$, gentamicin $(10 \mu \mathrm{g})$, tobramycin $(10 \mu \mathrm{g})$, imipenem $(10 \mu \mathrm{g})$, ciprofloxacin $(5 \mu \mathrm{g})$, piperacillin/ tazobactam $(100 \mu \mathrm{g} / 10 \mu \mathrm{g})$, cefotaxime $(30 \mu \mathrm{g})$, cefazolin $(30 \mu \mathrm{g})$, and cefuroxime $(30 \mu \mathrm{g})$ (Himedia laboratories, Mumbai, Maharashtra, India). The MIC for amikacin was determined by agar dilution method.

\section{Template DNA preparation}

A single bacterial colony was inoculated into Luria-Bertani broth (Himedia laboratories, Mumbai, Maharashtra, India) and incubated overnight at $37^{\circ} \mathrm{C}$, and it was then centrifuged at 10,000 rpm for $10 \mathrm{~min}$. The pellet was re-suspended in $250 \mu \mathrm{l}$ of Millipore water, boiled at $100^{\circ} \mathrm{C}$ for $10 \mathrm{~min}$, and cooled and centrifuged at $10,000 \mathrm{rpm}$ for $10 \mathrm{~min}$. The supernatant served as the template DNA.

\section{Polymerase chain reaction}

Four sets of multiplex PCRs were carried out using the previously described primers and conditions ${ }^{[14-19]}$ for all the study isolates. The multiplex primers used for different sets of genes, their annealing temperature, and the amplicon size are listed in Table 1.

Each reaction volume contained $2 \mu \mathrm{l}$ of the DNA template added to the master mix which includes 10 pmol of the forward and reverse primers (Sigma-Aldrich, Missouri, United States), 10 Mm dNTPs (Takara, Shiga, Japan), 5U taq polymerase (Takara, Shiga, Japan), and 10X buffer with $\mathrm{MgCl}_{2}$ (Takara, Shiga, Japan).

Amplification reactions were performed under the following conditions: initial denaturation at $95^{\circ} \mathrm{C}$ for $4 \mathrm{~min}$, followed by 32 cycles of denaturation at $94^{\circ} \mathrm{C}$ for $30 \mathrm{~s}$, annealing based on the primer employed for $30 \mathrm{~s}$ 
Table 1: Primers used for performing polymerase chain reaction for amplifying resistant genes

\begin{tabular}{|c|c|c|c|c|}
\hline Multiplex set & gene & Primer & Annealing temperature $\left({ }^{\circ} \mathrm{C}\right)$ & Amplicon size (bp) \\
\hline \multirow[t]{6}{*}{1} & \multirow[t]{2}{*}{$\operatorname{armA}$} & F-CCGAAATGACAGTTCCTATC & \multirow[t]{6}{*}{52} & \multirow[t]{2}{*}{864} \\
\hline & & R-GAAAATGAGTGCCTTGGAGG & & \\
\hline & \multirow[t]{2}{*}{$r m t B$} & F-GCT TTC TGC GGG CGA TGT AA & & \multirow[t]{2}{*}{173} \\
\hline & & R-ATG CAA TGC CGC GCT CGT AT & & \\
\hline & \multirow[t]{2}{*}{$r m t C$} & F-CGA AGA AGT AAC AGC CAA AG & & \multirow[t]{2}{*}{711} \\
\hline & & R-ATC CCA ACA TCT CTC CCA CT & & \\
\hline \multirow[t]{6}{*}{2} & \multirow[t]{2}{*}{$b l a_{T E M}$} & F- TTTCGTGTCGCCCTTATTCC & \multirow[t]{6}{*}{60} & \multirow[t]{2}{*}{404} \\
\hline & & R-ATCGTTGTCAGAAGTAAGTTGG & & \\
\hline & \multirow[t]{2}{*}{$b l a_{S H V}$} & F- CGCCTGTGTATTATCTCCCT & & \multirow[t]{2}{*}{294} \\
\hline & & R- CGAGTAGTCCACCAGATCCT & & \\
\hline & \multirow{2}{*}{$b / a_{C T X-M}$} & F- CGCTGTTGTTAGGAAGTGTG & & \multirow[t]{2}{*}{754} \\
\hline & & R- GGCTGGGTGAAGTAAGTGAC & & \\
\hline \multirow[t]{10}{*}{3} & \multirow{2}{*}{$b^{b l a}{ }_{I M P}$} & F- GGAATAGAGTGGCTTAAYTC & \multirow[t]{10}{*}{55} & \multirow[t]{2}{*}{232} \\
\hline & & R-TCGGTTTAAYAAAACAACCACC & & \\
\hline & \multirow{2}{*}{$b l a_{V I M}$} & F-GATGGTGTTTGGTCGCATA & & \multirow[t]{2}{*}{390} \\
\hline & & R- CGAATGCGCAGCACCAG & & \\
\hline & \multirow{2}{*}{ bla $_{\text {OXA-48-like }}$} & F- GCGTGGTTAAGGATGAACAC & & \multirow[t]{2}{*}{438} \\
\hline & & R- CATCAAGTTCAACCCAACCG & & \\
\hline & \multirow[t]{2}{*}{$b l a_{N D M}$} & F -GGTTTGGCGATCTGGTTTTC & & \multirow[t]{2}{*}{621} \\
\hline & & R -CGGAATGGCTCATCACGATC & & \\
\hline & \multirow[t]{2}{*}{$b l a_{K P C}$} & F- CGTCTAGTTCTGCTGTCTTG & & \multirow[t]{2}{*}{798} \\
\hline & & R- CTTGTCATCCTTGTTAGGCG & & \\
\hline \multirow[t]{6}{*}{4} & \multirow[t]{2}{*}{ qnrA } & F- TCAGCAAGAGGATTTCTCA & \multirow[t]{6}{*}{52} & 516 \\
\hline & & R- GGCAGCACTATTACTCCCA & & \\
\hline & $q n r B$ & F- GATCGTGAAAGCCAGAAAGG & & 469 \\
\hline & & R- ACGATGCCTGGTAGTTGTCC & & \\
\hline & qnrs & F- ACGACATTCGTCAACTGCAA & & 417 \\
\hline & & R- TAAATTGGCACCCTGTAGGC & & \\
\hline Simplex & $\operatorname{acc}\left(6^{\prime}\right) \mathrm{lb}-\mathrm{cr}$ & F- TTGGAAGCGGGGACGGA & 53 & 260 \\
\hline & & R- ACACGGCTGGACCATA & & \\
\hline
\end{tabular}

with an extension at $72^{\circ} \mathrm{C}$ for $50 \mathrm{~s}$, and a final extension for one cycle at $72^{\circ} \mathrm{C}$ for $5 \mathrm{~min}$. The PCR product was then run on a $1.5 \%$ agarose gel for detection of the amplified fragment. Strains previously confirmed by PCR were sequenced and used as positive controls.

\section{Bacterial conjugation}

Mating-out assays were performed at $37^{\circ} \mathrm{C}$ using Escherichia coli J53 as recipient, and the donors were the isolates which were positive for $16 \mathrm{~S}$ methylases along with $b l a_{N D M^{\prime}}$ and bla $a_{O X A-48-l i k e}$ genes. The transconjugants were screened on MacConkey agar plate containing $100 \mu \mathrm{g}$ of sodium azide (Himedia Laboratories, Mumbai, Maharashtra, India) along with $10 \mu \mathrm{g}$ of cefoxitin ${ }^{[20]}$ and $4 \mu \mathrm{g}$ of amikacin ${ }^{[21]}$ (SRL Pvt. Ltd, Mumbai, Maharashtra, India) each. The transconjugants were subjected to PCR detection of the antibiotic-resistant genes to confirm the transfer from the donor to the recipients.

\section{Plasmid-based replicon typing}

Plasmid-Inc group for the transconjugants was determined by plasmid-based replicon typing (PBRT) performed as described by Carattoli et al. ${ }^{[12]}$ The 18 Inc groups tested were HI1, HI2, I1- $\alpha \gamma$, X, L/M, N, FIA, FIB,
W, Y, P, FIC, A/C, T, FIIAs, F, K, and B/O.

PBRT was carried out in Applied Biosystems (Vetri 96-well thermal cycler, Pittsburgh, Pennsylvania) with five different multiplex-PCRs and three simplex-PCRs under the following conditions: all the amplifications were performed with the following amplification scheme: cycle of denaturation at $94^{\circ} \mathrm{C}$ for $5 \mathrm{~min}$, followed by 30 cycles of denaturation at $94^{\circ} \mathrm{C}$ for $1 \mathrm{~min}$, annealing at $60^{\circ} \mathrm{C}$ for all the Inc groups except that of $\mathrm{F}$ Inc group simplex which anneals at $52^{\circ} \mathrm{C}$ for $30 \mathrm{~s}$ with an extension at $72^{\circ} \mathrm{C}$ for $50 \mathrm{~s}$, and a final extension for one cycle at $72^{\circ} \mathrm{C}$ for $5 \mathrm{~min}$. The amplicon was then run on a $1.5 \%$ agarose gel for detection of the amplified fragment, and its corresponding Inc group was identified. The primers used for both multiplex- and simplex-PCRs performed are summarized in Table 2.

\section{Results}

The study isolates exhibited resistance to all the antimicrobials tested by disc diffusion method.

A high degree of resistance to amikacin 
Table 2: Primers used for replicon typing

\begin{tabular}{|c|c|c|c|c|}
\hline Multiplex set & Replicon type & Primer & Annealing temperature $\left({ }^{\circ} \mathrm{C}\right)$ & Amplicon size (bp) \\
\hline \multirow[t]{6}{*}{1} & $\mathrm{HI} 1$ & F- GGAGCGATGGATTACTTCAGTAC & 60 & 471 \\
\hline & & R-TGCCGTTTCACCTCGTGAGTA & & \\
\hline & HI2 & F- TTTCTCCTGAGTCACCTGTTAACAC & & 644 \\
\hline & & R- GGCTCACTACCGTTGTCATCCT & & \\
\hline & 11 & F- CGAAAGCCGGACGGCAGAA & & 139 \\
\hline & & R-TCGTCGTTCCGCCAAGTTCGT & & \\
\hline \multirow[t]{6}{*}{2} & $x$ & F-AACCTTAGAGGCTATTTAAGTTGCTGAT & 60 & 376 \\
\hline & & R-TGAGAGTCAATTTTTATCTCATGTTTTAGC & & \\
\hline & $\mathrm{L} / \mathrm{M}$ & F- GGATGAAAACTATCAGCATCTGAAG & & 785 \\
\hline & & R- CTGCAGGGGCGATTCTTTAGG & & \\
\hline & $\mathrm{N}$ & F- GTCTAACGAGCTTACCGAAG & & 559 \\
\hline & & R-GTTTCAACTCTGCCAAGTTC & & \\
\hline \multirow[t]{6}{*}{3} & FIA & F-CCATGCTGGTTCTAGAGAAGGTG & 60 & 462 \\
\hline & & R -GTATATCCTTACTGGCTTCCGCAG & & \\
\hline & FIB & F-GGAGTTCTGACACACGATTTTCTG & & 308 \\
\hline & & R-CTCCCGTCGCTTCAGGGCATT & & \\
\hline & W & F-CCTAAGAACAACAAAGCCCCCG & & 242 \\
\hline & & R-GGTGCGCGGCATAGAACCGT & & \\
\hline \multirow[t]{6}{*}{4} & Y & F-AATTCAAACAACACTGTGCAGCCTG & 60 & 765 \\
\hline & & R-GCGAGAATGGACGATTACAAAACTTT & & \\
\hline & $\mathrm{P}$ & F-CTATGGCCCTGCAAACGCGCCAGAAA & & 534 \\
\hline & & R-TCACGCGCCAGGGCGCAGCC & & \\
\hline & $\mathrm{FIC}$ & F-GTGAACTGGCAGATGAGGAAGG & & 262 \\
\hline & & R-TTCTCCTCGTCGCCAAACTAGAT & & \\
\hline \multirow[t]{6}{*}{5} & $\mathrm{~A} / \mathrm{C}$ & F-GAGAACCAAAGACAAAGACCTGGA & 60 & 465 \\
\hline & & R-ACGACAAACCTGAATTGCCTCCTT & & \\
\hline & $\mathrm{T}$ & F-TTGGCCTGTTTGTGCCTAAACCAT & & 750 \\
\hline & & R-CGTTGATTACACTTAGCTTTGGAC & & \\
\hline & $\mathrm{FII}_{\mathrm{s}}$ & F-CTGTCGTAAGCTGATGGC & & 270 \\
\hline & & R-CTCTGCCACAAАCTTCAGC & & \\
\hline \multirow[t]{2}{*}{ Simplex 1} & $\mathrm{~F}_{\text {repB }}$ & F-TGATCGTTTAAGGAATTTTG & 52 & 270 \\
\hline & & R-GAAGATCAGTCACACCATCC & & \\
\hline \multirow[t]{2}{*}{ Simplex 2} & $\mathrm{~K} / \mathrm{B}$ & F-GCGGTCCGGAAAGCCAGAAAA & 60 & 160 \\
\hline & & R-TCTTTCACGAGCCCGCCAAA & & \\
\hline \multirow[t]{2}{*}{ Simplex 3} & $\mathrm{~B} / \mathrm{O}$ & F-GCGGTCCGGAAAGCCAGAAAA & 60 & 159 \\
\hline & & R-TCTGCGTTCCGCCAAGTTCGA & & \\
\hline
\end{tabular}

(MIC range of $>512 \mu \mathrm{g} / \mathrm{mL}$ ) was observed in all the study isolates.

PCR screening revealed that, of the 117 isolates, $79(67.52 \%)$ harbored $\operatorname{arm} A, 19(16.23 \%) \mathrm{rmtB}$, and 16 carried (13.67\%) $r m t C$. Of these, four isolates harbored more than one $16 \mathrm{~S}$ rRNA methyltransferase. $b l a_{N D M}$ and $b l a_{O X A-48-l i k e}$ were detected in $60(51.28 \%)$ and 25 isolates (21.36\%), respectively. The co-occurrence of $b l a_{N D M}$ and $b l a_{O X A-48-l i k e}$ carbapenamase was observed in seven isolates, along with one of the 16S rRNA methyltransferases. Other carbapenemases such as $b l a_{I P M^{\prime}} b l a_{V I M^{\prime}}$ and $b l a_{K P C}$ were not encountered.

The other resistance-encoding genes detected were Qnr determinant (48), acc (6') Ib-cr (72), bla ${ }_{\text {TEM }}(4)$, and $b l a_{C T X-M}(9)$. Sixty isolates co-harbored $b l a_{T E M^{\prime}} b l a_{S H V^{\prime}}$ and $b l a_{C T X-M}$. The occurrence of these genes with $b l a_{N D M^{\prime}}$ bla $a_{\text {OXA-48-like }}$ and 16S rRNA methyltransferase is depicted in Table 3.
Conjugation experiment was carried out for all the 7 out of 117 K. pneumoniae strains (KP1, KP48, KP98, KP124, KP231, KP297, and KP302) that co-harbored both bla ${ }_{N D M}$ and bla $a_{\text {OXA-48-like }}$ carbapenamases, along with one of the 16S rRNA methyltransferases. The conjugation yield products, namely the single transconjugant, their plasmid replicon type, the resistance genes, and their associated resistant determinants, are tabulated [Table 4].

Out of the seven isolates that were conjugatively transferable, only four isolates had $b l a_{N D M}$ and $b l a_{\text {OXA-48-like }}$ on the same plasmid, and they belonged to replicon-Inc $\mathrm{N}$ and $\mathrm{A} / \mathrm{C}$. Of them, two isolates harbored only a single plasmid. One K. pneumoniae harbored two 16S rRNA methyltransferases arm $A$ and $r m t B$.

\section{Discussion}


Table 3: Number of isolates associated with the most common 16S rRNA methyltransferases along with other resistant determinants

\begin{tabular}{|c|c|c|c|c|c|c|}
\hline Genes & $\begin{array}{c}\text { armA } \\
\text { positives } \\
(n=79)\end{array}$ & $\begin{array}{l}\text { rmtB positives } \\
(n=19)\end{array}$ & $\begin{array}{c}\text { srmtC positives } \\
\qquad(n=16)\end{array}$ & $\begin{array}{c}\text { armA+rmtB } \\
\text { positives }(n=2)\end{array}$ & $\begin{array}{c}r m t B+r m t C \\
\text { positives }(n=2)\end{array}$ & $\begin{array}{c}\text { armA+rmtCl } \\
\operatorname{armA+rmtB}+r m t C \\
(n=0)\end{array}$ \\
\hline$b / a_{\mathrm{NDM}}(n=60)$ & 36 & 12 & 12 & - & - & - \\
\hline bla $_{\text {OXA-48- like }}(n=25)$ & 20 & 3 & 2 & - & - & - \\
\hline$b l a_{\mathrm{NDM}}+b / a_{\mathrm{OXA}-48}(n=7)$ & 3 & 1 & 1 & 2 & - & - \\
\hline$b l a_{\mathrm{IMP} / \mathrm{VIM} / \mathrm{KPC}}(n=0)$ & - & - & - & - & - & - \\
\hline bla $_{T E M}(n=4)$ & 2 & 2 & - & - & - & - \\
\hline$b l a_{S H V}(n=0)$ & - & - & - & - & - & - \\
\hline$b l a_{C T X-M}(n=9)$ & 3 & 2 & 4 & - & - & - \\
\hline$b l a_{T E M}+b l a_{S H V}(n=18)$ & 12 & 3 & 2 & 1 & - & - \\
\hline$b l a_{S H V}+b l a_{C T X-M}(n=7)$ & 2 & 5 & - & - & - & - \\
\hline$b l a_{T E M}+b l a_{C T X-M}(n=7)$ & 3 & 1 & 1 & - & 2 & - \\
\hline$b l a_{T E M}+b l a_{S H V}+b l a_{C T X-M}(n=70)$ & 45 & 5 & 9 & 1 & - & - \\
\hline qnr determinants $(n=48)$ & 32 & 6 & 4 & 1 & - & - \\
\hline aac (6')-lb-cr $(n=71)$ & 47 & 11 & 10 & 1 & 2 & - \\
\hline
\end{tabular}

Table 4: Isolates that co-harbored $b / a_{N D M}$ and bla ${ }_{O X A-48-l i k e}$ along with their resistant determinants and plasmid-incompatible groups

\begin{tabular}{|c|c|c|c|c|}
\hline $\begin{array}{l}\text { Isolate } \\
\text { number }\end{array}$ & Source & Donor-resistant determinants & Transconjugant-resistant determinants & $\begin{array}{l}\text { Plasmid-incompatible } \\
\text { group }\end{array}$ \\
\hline KP1 & Exudates & $b l a_{N D M}, b l a_{O X A-48-l i k e}, a r m A, b l a_{T E M}, b l a_{S H V}$ bla $a_{C T X-M}$ & $b l a_{\text {OXA-48-like, }}$, armA, bla $a_{T E M}, b l a_{C T X-M}$ & L/M \\
\hline KP48 & Respiratory & $b a_{N D M}, b l a_{O X A-48-l i k e}, r m t C$ & bla $_{\text {NDM, }}$, bla $a_{\text {OXA48-like, }}, \mathrm{rmtC}$ & $\mathrm{N}$ \\
\hline KP98 & Urine & $\begin{array}{l}\text { bla }_{N D M}, \text { bla } \\
\text { bla }_{C T X-M}, \text { aac }\left(6^{\prime}\right)-l i k-c r, \text { arm }, \text { rmtB }, \text { bla }\end{array}$ & $\begin{array}{l}b^{b l a} a_{N D M}, \operatorname{armA}, r m t B, b l a_{C T X-M}, \text { aac }\left(6^{\prime}\right)-l b-c r, \\
q n r B\end{array}$ & $A / C$ \\
\hline KP124 & Urine & $\begin{array}{l}b^{b l a_{N D M},} \text { bla } \\
\text { aac }\left(6^{\prime}\right)-I b-c r-48-l i k e \\
\text {, rmtB, bla }\end{array}$ & bla ${ }_{N D M}, b l a_{O X A-48-l i k e}, b l a_{C T X-M}$ & $\mathrm{~N}$ \\
\hline KP231 & Urine & $\begin{array}{l}\text { bla } a_{N D M}, b l a_{O X A-48-l i k e}, a r m A, r m t B, b l a_{T E M}, b l a_{S H V} \\
\text { aac }\left(6^{\prime}\right)-l b-c r\end{array}$ & $\begin{array}{l}\text { bla }_{\text {NDM, }} \text { bla } a_{\text {OXA-48-like, }}, \mathrm{rmtB}, \text { armA, bla } \\
\text { aac }\left(6^{\prime}\right)--1 b-c r\end{array}$ & $\mathrm{~A} / \mathrm{C}$ \\
\hline KP297 & Blood & $b l a_{N D M}, b l a_{O X A-48-l i k e}, a r m A, b l a_{T E M}, b l a_{S H V}$ bla $a_{C T X-M}$ & $b l a_{O X A-48-l i k e}, a r m A, b l a_{T E M}, b l a_{C T X-M}$ & $\mathrm{~N}$ \\
\hline KP302 & Urine & $\begin{array}{l}\text { bla }_{\text {NDM }}, \text { bla } \\
\text { aac }\left(6^{\prime}\right)-l b-c r\end{array}$ & 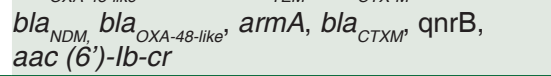 & $\mathrm{A} / \mathrm{C}$ \\
\hline
\end{tabular}

K. pneumoniae is a common enterobacterial pathogen causing healthcare-associated infections such as bacteremia, urinary tract infection, pneumonia, and meningitis. The rampant usage of antibiotics is modeling the bacteria to exhibit a phenomenal change in the drug susceptibility pattern with remarkable changes at their genetic level. ${ }^{[21]}$

All the 117 K. pneumoniae isolates exhibited high-level resistance to amikacin with an MIC $>512 \mu \mathrm{g} / \mathrm{mL}$. Such high levels of resistance are attributable to the use of S-adenyosyl-L-methionine as a co-substrate and methylation of the aminoglycoside-binding A-site of the $16 \mathrm{~S}$ rRNA of the bacterial ribosome. ${ }^{[22]}$

The plasmid-mediated 16S rRNA methyltransferase usually exhibits a strong linkage with multidrug-resistant determinants. ${ }^{[23]}$ Among the ESBLs, bla ${ }_{T E M^{\prime}}$ bla ${ }_{S H V}$, and bla $a_{C T \text { X-M }}$ were the most frequently encountered [Table 3]. Similar to our observation, the coexistence of these in Enterobacteriaceae has been reported from India previously. ${ }^{[24-26]}$
In this study, the prevalence of $\operatorname{arm} A(67.52 \%)$ was high when compared to that of $r m t B(16.23 \%)$ and $\operatorname{rmtC}(13.67 \%)$. The greater occurrence of $\operatorname{arm} A$ is presumably due to its co-existence with $b l a_{C T X-M}$ on the same plasmid and its location on an effective transposon Tn1548. ${ }^{[27]}$

The presence of more than one $16 \mathrm{~S}$ rRNA methyltransferase is seldom reported. Interestingly, we found four isolates (3.41\%) harboring multiple 16S rRNA methyltransferases in combinations of $\operatorname{arm} A+\operatorname{rmt} B$ and $\operatorname{rmt} B+\operatorname{rmt} C$. The occurrence of more than one $16 \mathrm{~S}$ rRNA methylases in our study was low as compared to a report from Northeast India ${ }^{[5]}$ where it was observed in $27.64 \%$ of E. coli.

In a report from Morocco,, ${ }^{[28]}$ only 2 out of 116 aminoglycoside-resistant $K$. pneumoniae harbored both bla $a_{N D M}$ and aac (6')-Ib-cr. In this study, a higher proportion (46/117) co-harbored the above determinants, which is a cause for worry because it restricts the application of combination therapy. 
Most of the $b l a_{N D M}$-harboring plasmids are usually untypeable, ${ }^{[29]}$ whereas $b l a_{\text {OXA-48-ike }}$ plasmids are associated with IncL/M. The $b l a_{N D M}$ producers can co-harbor other beta-lactamases and/or 16SrRNA methyltransferase genes ( $\operatorname{arm} A, r m t B$, and $r m t C$ ). However, the co-occurrence of $b l a_{N D M}$ and $b l a_{\text {OXA-48-like }}$ in a single plasmid is rarely reported. ${ }^{[30]}$

In the present study, seven isolates harboring $b l a_{N D M}$ and bla $a_{\text {OXA-48-like }}$ along with 16S rRNA methyltransferase were conjugatively transferable. The incompatibility typing of plasmids revealed that $\operatorname{arm} A$ was encoded within $\mathrm{L} / \mathrm{M}-$, $\mathrm{A} / \mathrm{C}-$, and $\mathrm{N}$-Inc groups, whereas, $r m t B$ and $r m t C$ were encoded within A/C- and N-Inc groups, respectively. Two isolates which anchored both arm $A$ and $r m t B$ were encoded within a single Inc group A/C. This pattern is in accordance with the report from North India ${ }^{[5]}$ where multiple $16 \mathrm{~S}$ methyltransferase genes were found on diverse Inc group types such as FIB, FIIS, I, T, X, N, Y, $\mathrm{L} / \mathrm{M}$, and FIA. By PBRT, the $b l a_{N D M}$ and $b l a_{\text {OXA48-like }}$ were encoded within plasmids belonging to $\mathrm{L} / \mathrm{M}-, \mathrm{A} / \mathrm{C}-$-, and $\mathrm{N}$-Inc groups. Previously, Soundari et al. have reported the presence of both $b l a_{N D M}$ and bla $a_{\text {OXA48-like }}$ in IncHI3 replicon. ${ }^{[29]}$

\section{Conclusion}

Our findings underline the emerging threat of multidrug-resistant pathogens that produce 16S rRNA methylase disseminating in this region.

This study is of epidemiological importance. There is co-occurrence of two 16SrRNA methyltransferases along with bla $a_{N D M}$ and bla $a_{O X A 48-l i k e}$ on single-plasmid replicon, and they belong to Inc A/C. To the best of our knowledge, this is the first report of such an occurrence till date. However, multi- centric studies needs to be carried out with increased sample size to have a better understanding about the different plasmid Inc types involved, their diverse source of origin and acquisition which would aid in the control strategies.

\section{Financial support and sponsorship}

This study was supported by the Department of Science and Technology under INSPIRE-fellowship scheme (reference number IF150368).

\section{Conflicts of interest}

There are no conflicts of interest.

\section{References}

1. Yokoyama K, Doi Y, Yamane K, Kurokawa H, Shibata N, Shibayama K, et al. Acquisition of $16 \mathrm{~S}$ rRNA methylase gene in Pseudomonas aeruginosa. Lancet 2003;362:1888-93.

2. Galimand M, Courvalin P, Lambert T. Plasmid-mediated high-level resistance to aminoglycosides in Enterobacteriaceae due to 16S rRNA methylation. Antimicrob Agents Chemother 2003;47:2565-71.

3. Rahman M, Prasad KN, Pathak A, Pati BK, Singh A, Ovejero CM, et al. RmtC and rmtF 16S rRNA methyltransferase in NDM-1-producing Pseudomonas aeruginosa. Emerg Infect Dis 2015;21:2059-62.

4. Ayad A, Drissi M, de Curraize C, Dupont C, Hartmann A, Solanas $\mathrm{S}$, et al. Occurrence of armA and rmtB aminoglycoside resistance 16S rRNA methylases in extended-spectrum $\beta$-lactamases producing Escherichia coli in Algerian hospitals. Front Microbiol 2016;7:1409.

5. Wangkheimayum J, Paul D, Dhar D, Nepram R, Chetri S, Bhowmik D, et al. Occurrence of acquired 16S rRNA methyltransferase-mediated aminoglycoside resistance in clinical isolates of Enterobacteriaceae within a tertiary referral hospital of Northeast India. Antimicrob Agents Chemother 2017;61:e01037-16.

6. Berçot B, Poirel L, Nordmann P. Updated multiplex polymerase chain reaction for detection of $16 \mathrm{~S}$ rRNA methylases: High prevalence among NDM-1 producers. Diagn Microbiol Infect Dis 2011;71:442-5.

7. Bakour S, Alsharapy SA, Touati A, Rolain JM. Characterization of Acinetobacter baumannii clinical isolates carrying bla (OXA-23) carbapenemase and 16S rRNA methylase ArmA genes in Yemen. Microb Drug Resist 2014;20:604-9.

8. Karah N, Haldorsen B, Hermansen NO, Tveten Y, RagnhildstveitE, Skutlaberg DH, et al. Emergence of OXA-carbapenemase-And 16S rRNA methylase-producing international clones of Acinetobacter baumannii in Norway. J Med Microbiol 2011;60:515-21.

9. Balm MN, La MV, Krishnan P, Jureen R, Lin RT, Teo JW. Emergence of Klebsiella pneumoniae co-producing NDM-type and OXA-181 carbapenemases. Clin Microbiol Infect 2013;19:E421-3.

10. Gokmen TG, Nagiyev T, Meral M, Onlen C, Heydari F, Koksal F. NDM-1 and rmtC-producing Klebsiella pneumoniae isolates in Turkey. Jundishapur J Microbiol 2016;9:e33990.

11. Poirel L, Dortet L, Bernabeu S, Nordmann P. Genetic features of blaNDM-1-positive Enterobacteriaceae. Antimicrob Agents Chemother 2011;55:5403-7.

12. Carattoli A, Bertini A, Villa L, Falbo V, Hopkins KL, Threlfall EJ. Identification of plasmids by PCR-based replicon typing. J Microbiol Methods 2005;63:219-28.

13. Clinical and Laboratory Standards Institute. Performance Standards for Antimicrobial Susceptibility Testing. CLSI Supplement M100S. CLSI Supplement M100S. Wayne, PA: Clinical and Laboratory Standards Institute; 2016.

14. Yan JJ, Wu JJ, Ko WC, Tsai SH, Chuang CL, Wu HM, et al. Plasmid-mediated 16S rRNA methylases conferring high-level aminoglycoside resistance in Escherichia coli and Klebsiella pneumoniae isolates from two Taiwanese hospitals. J Antimicrob Chemother 2004;54:1007-12.

15. Doi Y, Arakawa Y. 16S ribosomal RNA methylation: Emerging resistance mechanism against aminoglycosides. Clin Infect Dis 2007;45:88-94.

16. Nordmann P, Naas T, Poirel L. Global spread of carbapenemase-producing Enterobacteriaceae. Emerg Infect Dis 2011;17:1791-8.

17. Hassan MI, Alkharsah KR, Alzahrani AJ, Obeid OE, Khamis AH, Diab A. Detection of extended spectrum beta-lactamases-producing isolates and effect of AmpC overlapping. J Infect Dev Ctries 2013;7:618-29.

18. Robicsek A, Strahilevitz J, Sahm DF, Jacoby GA, Hooper DC. Qnr prevalence in ceftazidime-resistant Enterobacteriaceae isolates from the United States. Antimicrob Agents Chemother 2006;50:2872-4.

19. Wareham DW, Umoren I, Khanna P, Gordon NC. Allele-specific polymerase chain reaction (PCR) for rapid detection of the aac (6')-Ib-cr quinolone resistance gene. Int J Antimicrob Agents 2010;36:476-7.

20. Potron A, Poirel L, Nordmann P. Plasmid-mediated transfer of 
the bla (NDM-1) gene in gram-negative rods. FEMS Microbiol Lett 2011;324:111-6.

21. Wang H, Chen M, Ni Y, Liu Y, Sun H, Yu Y, et al. Antimicrobial resistance among clinical isolates from the Chinese meropenem surveillance study (CMSS), 2003-2008. Int J Antimicrob Agents 2010;35:227-34.

22. WachinoJ, Arakawa Y.Exogenously acquired $16 \mathrm{SrRNA}$ methylases found in aminoglycoside- resistant pathogenic gram negative bacteria: An update. Drug Resist Updat 2012;15:133-48.

23. Yang J, Ye L, Wang W, Luo Y, Zhang Y, Han L, et al. Diverse prevalence of $16 \mathrm{~S}$ rRNA methylase genes armA and $\mathrm{rmtB}$ amongst clinical multidrug-resistant Escherichia coli and Klebsiella pneumoniae isolates. Int J Antimicrob Agents 2011;38:348-51.

24. Manoharan A, Premalatha K, Chatterjee S, Mathai D; SARI Study Group. Correlation of TEM, SHV and CTX-M extended-spectrum beta lactamases among Enterobacteriaceae with their in vitro antimicrobial susceptibility. Indian J Med Microbiol 2011;29:161-4.

25. Goyal A, Prasad KN, Prasad A, Gupta S, Ghoshal U, Ayyagari A. Extended spectrum beta-lactamases in Escherichia coli and Klebsiella pneumoniae and associated risk factors. Indian J Med
Res 2009;129:695-700.

26. Veeraraghavan B, Shankar C, Karunasree S, Kumari S, Ravi R, Ralph R. Carbapenem resistant Klebsiella pneumoniae isolated from bloodstream infection: Indian experience. Pathog Glob Health 2017;111:240-6.

27. Galimand M, Sabtcheva S, Courvalin P, Lambert T. Worldwide disseminated armA aminoglycoside resistance methylase gene is borne by composite transposon Tn1548. Antimicrob Agents Chemother 2005;49:2949-53.

28. Barguigua A, Zerouali K, Katfy K, El Otmani F, Timinouni M, Elmdaghri $\mathrm{N}$, et al. Occurrence of OXA-48 and NDM-1 carbapenemase-producing Klebsiella pneumoniae in a Moroccan University hospital in Casablanca, Morocco. Infect Genet Evol 2015;31:142-8.

29. Soundari PG, Vijyakumar R, Krishnan P. Abstracts of the $27^{\text {th }}$ European Congress of Clinical Microbiology and Infectious Diseases. Vienna, Austria; 2017.

30. Poirel L, Lagrutta E, Taylor P, Pham J, Nordmann P. Emergence of metallo- $\beta$-lactamase NDM-1-producing multidrug-resistant Escherichia coli in Australia. Antimicrob Agents Chemother 2010;54:4914-6. 